\title{
Increased incidence of Mycoplasma pneumoniae infection in Norway 2011
}

H Blystad (hans.blystad@fhi.no)'1, G Ånestad ${ }^{1}$, D F Vestrheim ${ }^{1}$, S Madsen², K Rønning ${ }^{1}$

1. Norwegian Institute of Public Health, Oslo, Norway

2. Norwegian Medicines Agency, Oslo, Norway

Epidemics of Mycoplasma pneumoniae have recently been reported from England and Wales and from Denmark. A similar increase in M. pneumoniae infections was noted in Norway late autumn 2011.The epidemic has resulted in shortage of erythromycin and the use of alternative antibiotics has been recommended.

\section{Background}

Following reports of epidemics of Mycoplasma pneumoniae in Denmark and England and Wales [1,2], special attention has been paid by the Norwegian Institute of Public Health to detect any similar increase in Norway. Surveillance of $M$. pneumoniae infections in Norway is solely based on a voluntary laboratory-based reporting system, and the disease is not notifiable in the Norwegian Surveillance System for communicable diseases.

\section{Surveillance of M. pneumoniae infections in Norway}

A voluntary laboratory-based reporting system where a selection of laboratories report to the Norwegian Institute of Public Health the number of patients testing positive for all laboratory-confirmed virus diagnoses as well as for $M$. pneumoniae each month has been in place since 1975 . The number of participating laboratories has varied over the years, but there have not been any major changes in the system during the last decades. At present, 16 of 21 diagnostic microbiological laboratories in Norway participate in this surveillance system. This covers more than $80 \%$ of the Norwegian population. A total of 12 laboratories, representing all regions of the country, submit data on the number of patients testing positive by serological or molecular tests for $M$. pneumoniae. There is no common case definition for reporting a positive result, and a positive serology may include a single high titre or a rise in $M$. pneumoniae-specific IgG antibody levels. Results obtained are indicative of the $M$. pneumoniae activity in Norway as a whole. Data on the total number of tests performed or age groups among patients with positive test results is not collected in this surveillance system. Monthly reports, available at Department of
Virology, Norwegian Institute of Public Health, are submitted to all the participating laboratories, and to others who may be interested.

Since a consensus meeting of clinical microbiologists in Norway in 2003 [3], polymerase chain reaction (PCR) tests have been recommended as the most specific method of choice for laboratory diagnosis of suspected M. pneumoniae infection of less than four weeks duration [3]. Serology may add value to the diagnosis of long-standing infection, either by the detection of increasing antibody levels in paired serum samples, or by high antibody levels in samples drawn at least two weeks after onset of symptoms. Concurrently, the proportion of reported cases identified by PCR increased, while the proportion reported by serology decreased.

The yearly number of $M$. pneumoniae-positive tests reported to the Norwegian Institute of Public Health for the period January 1984 to December 2011 is shown in Figure 1. This figure demonstrates regular recurrent epidemics of $M$. pneumoniae in Norway, occurring with five- to seven-year intervals (2011/12, 2006, 2000, 1993 and possibly also in 1987). During the period from 2007 until August 2011 the number of reported cases remained low. From September 2011 a sharp increase in tests positive for M. pneumoniae was observed. PCR and serology were both used in equal measures as diagnostic methods until the epidemic was identified. Hereafter most cases were diagnosed by PCR (Figure 2).

\section{Public health response}

Following the observed increase of reported positive tests for M. pneumoniae, respective information was published on the website of the Norwegian Institute of Public Health on 25 October 2011 [4]. This website is the main communication platform to clinicians as well as to the media and the public with regards to activity of various infectious diseases in Norway. In addition, a message was posted on a closed communication platform among laboratories in Norway, This communication platform was also used to obtain detailed 
descriptions of weekly numbers and proportions of M. pneumoniae cases from laboratories in all regions of the country in an ad hoc manner, adding to the surveillance by monthly reporting as described above.

Although most general practitioners and other clinicians are familiar with $M$. pneumoniae infections, these are not considered a well known disease among the general public. Little attention had been given to the last epidemic in 2006. In a new webposting on 7 December 2011 it was emphasised that not all suspected or confirmed cases of $M$. pneumoniae infection need antibiotic treatment [5], and if such treatment was indicated clinicians should chose antibiotics according to recommendations given in the national guidelines on the use of antibiotics in primary health care [6]. In these guidelines, erythromycin and doxycyclin are recommended as the drug of choice in the treatment

\section{FIGURE 1}

Number of laboratory-reported Mycoplasma pneumoniae infections by year, Norway January 1984 - December 2011

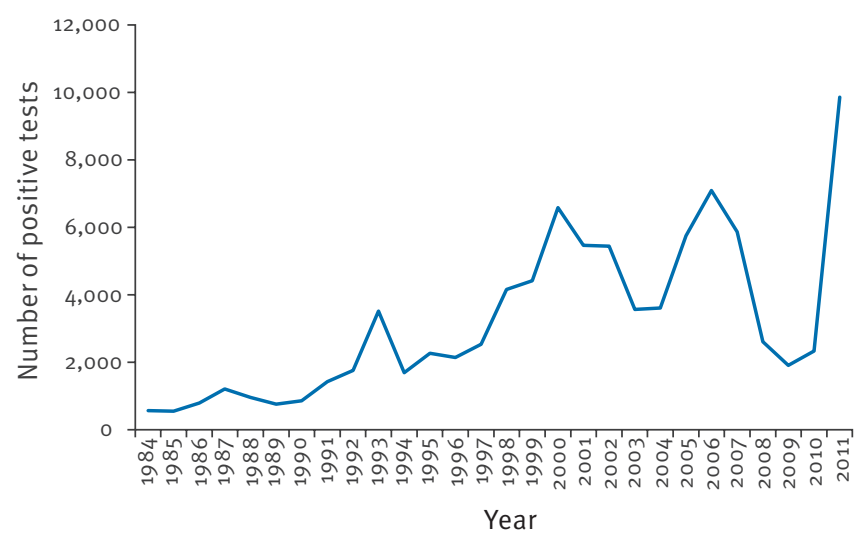

Source: Norwegian Institute of Public Health

\section{FIGURE 2}

Laboratory reports of Mycoplasma pneumoniae infection by diagnostic methods, Norway January 2010 - December 2011

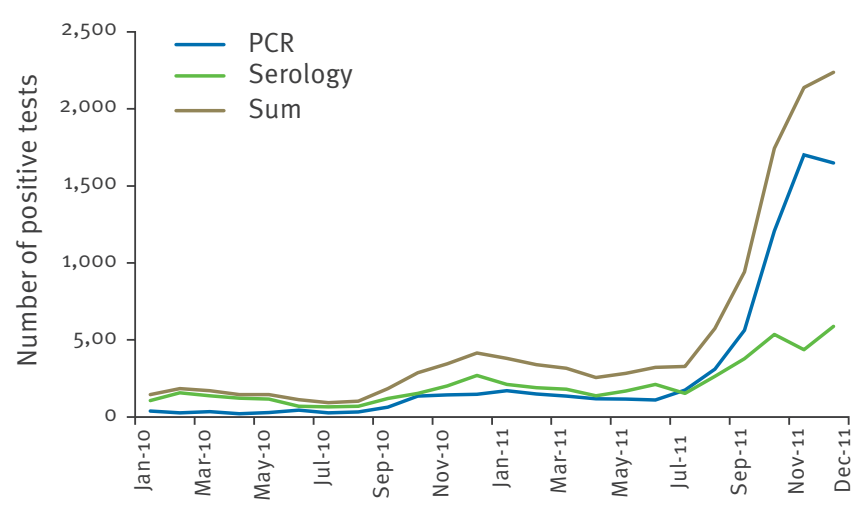

PCR: Polymerase chain reaction

Source: Norwegian Institute of Public Health of upper or lower respiratory infections caused by M. pneumoniae. Azithromycin is not recommended for the treatment of respiratory tract infections in Norway due risk of resistance development.

\section{Prescription of antibiotics}

In the two months following publication, a two-fold increase in prescription of erythromycin was seen in Norway compared with the previous months and the same months in 2010. Monthly sales of erythromycin in the period from January 2010 to December 2011 are shown in Figure 3. The reason behind this increase is thought to be extensive treatment with erythromycin in respiratory tract infections suspected to be caused by M. pneumoniae. Awareness of the current mycoplasma epidemic might have influenced testing activity for pathogens causing respiratory tract infections, leading to an increase of positive tests.

On 4 January 2012 the Norwegian Medicines Agency reported a shortage of erythromycin in the country expected to last until March-April 2012 [7]. Clarithromycin has been recommended as an alternative to erythromycin in the treatment of respiratory tract infections.

\section{Discussion and conclusion}

An epidemic of $M$. pneumoniae has been identified in Norway since September 2011 through voluntary laboratory-based surveillance reporting. The increase in erythromycin prescriptions seen since November 2011 is probably related to extensive and in many cases unnecessary antibiotic treatment of suspected or confirmed cases of $M$. pneumoniae infections. Awareness of the epidemic might have impacted both the laboratory testing rate and the prescription of antibiotics. The regularity in temporal timing of $M$. pneumoniae outbreaks may be used to foresee new epidemics in Norway. Unfortunately, the present reporting system of $M$. pneumoniae infections in Norway is not able to provide data on the overall testing activity for M. pneumoniae or other respiratory infections. A better

\section{FIGURE 3}

Monthly sales of erythromycin packages in Norway January 2010 - December 2011.

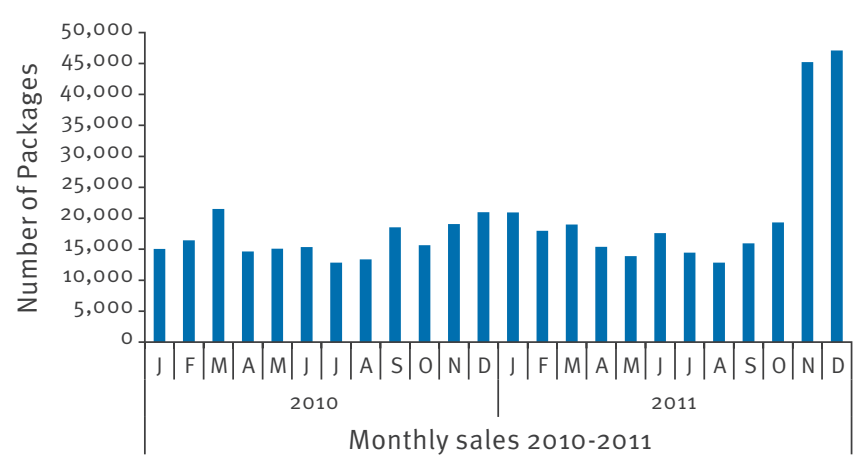

Source: Norwegian Medicines Agency 
laboratory-based surveillance system for identifying increase in seasonal and recurrent non-notifiable diseases infections is under consideration.

\section{Acknowledgments}

We acknowledge the following microbiological laboratories for providing data:

Department of Microbiology, Oslo University Hospital, Ullevål, Oslo; Department of Microbiology, Østfold Hospital, Fredrikstad; Department of Microbiology, Akershus University Hospital, Lørenskog; Department of Microbiology, Vestre Viken Hospital, Drammen; Department of Microbiology, Vestfold Hospital, Tønsberg ; Unilabs Telelab, Skien; Department of Microbiology, Sørlandet Hospital, Kristiansand; Department of Microbiology, Stavanger University Hospital, Stavanger; Department of Microbiology, Haukeland University Hospital, Bergen; Department of Microbiology, Molde Hospital, Molde; Department of Microbiology, St. Olav University Hospital, Trondheim; Department of Microbiology, Nordland Hospital, Bodø; Department of Microbiology, Troms $\varnothing$ University Hospital, Tromsø.

\section{References}

1. Rasmussen JN, Voldstedlund M, Andersen RL, EllermannEriksen S, Jensen TG, Johansen HK, et al. Increased incidence of Mycoplasma pneumoniae infections detected by laboratory-based surveillance in Denmark in 2010. Euro Surveill. 2010;15(45). pii=19708. Available from: http://www. eurosurveillance.org/ViewArticle.aspx?Articleld=19708

2. Chalker VJ, Stocki T, Mentasti M, Fleming D, Harrison TG et al. Increased incidence of Mycoplasma pneumoniae infection in England and Wales in 2010: multilocus variable number tandem repeat analysis typing and macrolide susceptibility. Euro Surveill. 2011;16(19). pii= 19865. Available from: http:// www.eurosurveillance.org/ViewArticle.aspx?Articleld=19865

3. Folkehelseinstituttet (FHI). Nedre luftveisinfeksjoner. Strategirapport nr 17. Oslo: FHI; 2003. Norwegian. Available from: http://www.fhi.no/dokumenter/oCAA869BE1.pdf

4. Folkehelseinstituttet FHI. Økt forekomst av Mycoplasma pneumoniae-infeksjoner. Oslo: FHI; 2011. Norwegian. Available from: http://www.fhi.no/eway/default.aspx?pid=233 \&trg=MainLeft 5588\&MainArea 5661=5588:0:15,1787:1:0:0::: 0:0\&MainLeft $5588=5544: 92470:: 1: 5567: 13::: 0: 0$

5. Folkehelseinstituttet FHI. Fortsatt økning i forekomsten av Mycoplasma pneumoniae-infeksjoner. Oslo: FHI; 2011. Norwegian. Available from: http://www.fhi.no/eway/default. aspx?pid=233\&trg=MainLeft_5588\&MainArea_5661=5588:0:1 5,1787:1:0:0:::0:0\&MainLeft_5588=5544:94394::1:5569:8:::0:0

6. Nasjonale faglige retningslinjer for antibiotikabruk $i$ primærhelsetjenesten [National guidelines for antibiotic use in Primary Health Care] Norwegian. Available from http:// www.helsedirektoratet.no/publikasjoner/nasjonal-fagligretningslinje-for-antibiotikabruk-i-primerhelsetjenesten/Sider/ default.aspx

7. Mangel på erytromycin. [Lack of erythromycin]. Legemiddelverket 4.1.2012. Norwegian. Available from http:// www.legemiddelverket.no/templates/InterPage 83373. aspx 